explain some cases of crime, so also do physical defects. One man dealt with under the Birmingham Scheme was found to be suffering from consumption, which had poisoned his mentality; he was sent to a sanatorium for consumptives, and now, after proper treatment, is a useful, law-abiding citizen. Is not this more practical than a heavy sentence of imprisonment?

\title{
THE BIRMINGHAM SCHEME-A REVIEW.*
}

\section{By M. HAMBLIN SMITH, M.D. (Medical Officer, H.M. Prison, Birrningham).}

In former days Courts contented themisclves by framing and applying what has been well termed "a tariff for crime," and this is still far too prevalent to-day. The legal mind finds it very. hard to escape from the bondage of this idea. "Fitting the punishnent to the crime," is absolutely opposed to the views of all modern criminologists. A particular criminal act cannot be taken as standing by itsclf. The act is only a symptom, and may be a quite unimportant symptom. The real question is not what a man has done, but what he is, nud the watchword to-day is not punishment, but treatment. There is always some abnormality in a criminal offender. For in the case of the "normal" or average man, the ordinary restraints are enough to keep him from committing acts against the law. Crime is a symptom of disease, and we have, if possible, to discover the cause of the disense. Only when this is known can we even lope to apply appropriate treatment. And the treatment of an offender, like the treatment of a patient, must always be individual and personal if it is to have any chance of success.

Every science advances by the study of causations, and there can be no reason why the science of conduct should be an exception to this rule. But the causes of anti-social conduct are many and varied. There are a vast number of influences, environments, physical, inherited, and the like, which may give an impulse towards delinquency. All these factors are, however, only operable in so far as they affect the offender's mental life. For it is a fundamental fact that conduct is the dirict result of mental life.

So the true function of a Court is that of a prescriber of treatment. And just as a modern physician calls to his aid all the expert specialists whom he can obtain-the X-ray operator, the bacteriologist, and the

- A Report, slightly abridged, presented to the Birmingham Juetices. October 26th, 1920. 
like-so no Court can afford to neglect any expert aid which may be at its disposal. Part of this aid is the cmployment of the expert mental examiner. Inquiry into the mental stnte of offenders is a very specialised matter, nuld it may be of a very intricate nature, and occupy a considerable period. To make such enquiries in a perfunctory manner is mere waste of time. It is essential also that the medical offeer should be an enthusiastic student of modern mental methods. Quite apart from the investigation of individual cases, there is an immense field for work in the general investigation of offenders.

In the examination of any offender :

(I) Physical disabilitics have to be taken into account, for I need not labour the point that these may be potent influences.

(2) Lunnatics only require naming, but the lunacy may only be discoverable after prolonged inquiry.

(3) Cases certifiable under the Mental Deficiency Act, which may be very difficult, though the difficulty is vastly incrensed when we come to-

(4) Defectives who are not certifiable uncler the Act. There are many of these; they present a grent problem, and it is becoming clear that ameniment in the law is necessary. We may also have defectives with some special ability and we may have normal or subnormal persons with some special defect.

(5) Epileptics require very careful consideration. The estimation of their responsibility is a very complicated matter. And this applics also to cases of "sltell-shock." The special susceptibility of some of these cases to the influence of alcohol is an important factor. Hysterical subjects require thought, and there are very rare cases of malingering.

(6) We have the various types of alcoholics, with their alcoholism and their hereditary or acquired mental instability acting and reacting upon cach other. Here again alteration in the law is highly desirable.

(a) I should become too technical if I began to discuss the latest discoveries in what is kuown as psycho-analysis. It must suffice to say that this great subject, as yot only in its infancy, will play an immense part in the mental examination of the future. Here again is a reason for the employment of experts; for this is not to be taken in hand lightly by anyone.

After physical examination for defects, we have to find out what our offender's formal education has been; what is his mental ability, general or special, apart from formal education; whether he has any abnormal mental functionings; whether he has any important characteristics of emotional or moral life which may lead to impulsive or other- 
wise abnormal action, and whether he has had any expcriences which may interfere with the healthy working of his mental life. Our findings in any particular case may be negative, but this fact may be of practical usefulness.

Such, in brief outline, is the problem, and to deal with it we, like the Court, require all the information as to the case which we can obtain. In this direction I am not satisfied that all which might be done is being done. It would be of great assistance if the available information as to family and personal history, environment, \&c., could be supplied in all cases sent for report. There might be objection in some cases to this information being gathered by the police. But it could, perhaps, be arranged in other ways. Facts as to the after career of cases deait with would also be of great interest and importance.

The ideal plan would be to examine every prisoner before he or she was sentenced by the Court. This is, at present, impracticable-we have not the necessary staff-so we have to concentrate on sclected cases. I need not point out that the work is much more promising in young offenders, than in those already fixed in criminal habits. The examination of alcoholic cases is also of importance. IT WOUID BE AN EXCKLLENT PLAN IF A PRHIIMINARY SURIEY OF ALL THE CASRS COUI,D BE HEI,D DAILY BEFORE THE WORK AT THE COURTS BEGAN. There are obvious difficulties, for this survey would have to be conducted by a doctor. It may be that, in the future, we shall be able to arrange something on these lines.

Some details as to the number of cases and the disposal theren will be found in the table on p. 85 . It will be noticed that imprisonment was resorted to in less than 26 per cent. of the cases.

As to my methods I would say a few words. I find it best to see each case, to commence with, for a short time each day. These first few days 1 converse with the subject on different topics, trying to win his confidence, to overcome any nervousness which may be present, to assure him that our only desire is to help him as far as may be, and to discover all I can as to his character, \&c. Shortly before the case goes to the Court I give a full mental examination. In all cases which are suitable I apply a scheme of mental tests which I have selected after prolonged experimentation. This scheme, I venture to think, avoids some of the drawbacks of certain other schemes, and gives one a good view of the subject's mental condition. A fairly confident diagnosis of defect of intelligence can be made on this. But this is not all. No one who has not worked a scheme of this kind can realise how much can be learned as to a subject's mental "make-up" by means of a suitable set of tests. One constantly gets indications of lack of concentration and attention, lack of perseverance, undue sus- 
ceptibility to the influence of suggestion, lnziness, \&.c. And, on the other hand, we may find special ability in some particular line.

Careful mental examination sometimes gives a clue to buried difficulties ("complexes") the finding and relief of which may alter the whole of the subject's life. Clearly na statistics can be given as to this, lutt in two cases I have had information as to the after-history of the subjects which has been of a most cncouraging character, and I felt more than repail for the very large expenditure of time which the procedure involved. The time required is one of the great difficultics in the extension of our scheme, but the future will remedy this. Workers will be fortheoming when the necessity of the work is realized.

Objection has been taken to the scheme on the ground of cost. But we have only to follow up the history of one criminal family to sec that uninvestignted offenders are the most expensive luxury in which any community can indulge. The objection has also been taken that the scheme takes the case out of the Justices' hands. This, of course, is not so in the slightest degree. The ultimate decision lies and always must lic with the Justices.

As to desirable alterations in the law. I think that the words "from bitth or an early nge" should be deleted from the Mental Deficiency Act. These words are a hindrance to dealing with many cases. Constant repetition of certain kinds of offences should be enough, in itself, to bring a case within the Act. I have in mind a man who has 35 convictions for indecent exposure, but who cannot be bronght within the Act as it stands. Then there should be power to detain cases which have been convicted and certified uncler the Act until they can be permanently provided for. We have received several defectives sentenced to such short periods that there has been no time to act before they were discharged. It seems to me that the Incbriates Act also requires amendment. The number of convictions qualifying for reformatory treatment should be lessened. At present the Act seems to be regarded as a last resort. Fnilure is, under these circumstances, inevitable. The only hope of success lies in getting such cases early.

I am strongly of opinion that the very short sentences which are still often given should be made impossible by law. If a man is to be sent to prison at all, he should be sent for a period of sufficient length to give reformatory influences a chance of success. And I think we might do more in the direction of better classification. Certain prisons might be reserved for special classes of prisoners. This is done now in the case of juvenile-ndults. There seems no good reason why all the prisoners from a given district should be retained in one prison. The grcat aim of all changes should be to promote the treatment of prisoners on individual lines. 
Cases sent for examination during year ending August 31st, 1920:Offences. Indecency, \&c., and soliciting prostitution ... 25 I 26 $\begin{array}{lllllllll}\text { Violence, } \& c . & \ldots & \ldots & \ldots & \ldots & \ldots & 10 & 2 & 12\end{array}$ $\begin{array}{lllllllll}\text { Larceny, \&c. } & \ldots & \ldots & \ldots & \ldots & \ldots & 25 & 2 & 27\end{array}$

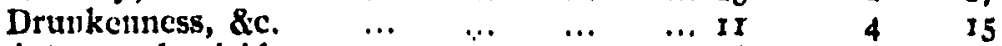
$\begin{array}{llllllll}\text { Attcmpted suicide } & \ldots & \ldots & \ldots & \ldots & \text { I8 } & \text { 12 } & \text { 30 }\end{array}$ $\begin{array}{llllllllll}\text { Other offences } & \ldots & \ldots & \ldots & \ldots & \ldots & 34 & 7 & 41\end{array}$

$\overline{123} \quad \overline{28} \quad \overline{151}$

Disposal of the Cases.

Males. Females. Total.

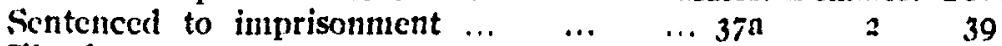
$\begin{array}{rrrrrrrrrr}\text { Fined } & \ldots & \ldots & \ldots & \ldots & \ldots & \ldots & 4 & 0 & 4\end{array}$ $\begin{array}{llllllll}\text { Placed on probation } & \ldots & \ldots & \ldots & \ldots & 4 & 4 \\ \end{array}$ $\begin{array}{lllllll}\text { Dismissed, adjourned, \&c. } & \ldots & \ldots & \ldots & 46 \mathrm{~b} & 1 ; & 59\end{array}$

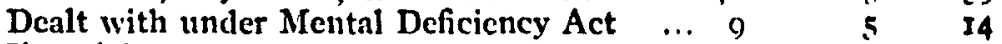

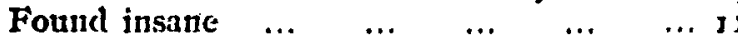
Found not guilty at Assizes or Sessions $\ldots$ ic $\quad$ I

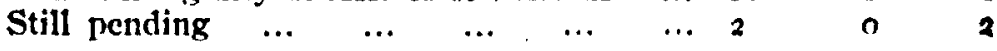

$\overline{123} \quad \overline{28} \quad \overline{151}$

a. 3 of these were dealt with Inter, under the Mental Deficiency Act. b. I of these was a mental defective.

c. This man was a mental defective.

\title{
THE MAGISTRATES' POINT OF VIEW.
}

\author{
By S. E. SHORT, J.P.
}

Acmber of Birmingham Justices' Special Committec on Mentally Defective Offenders; late Chairman of Visiting Justices, H,M. Prison, Birmingham).

The experiment recently instituted in Birmingham has placed at the disposal of the Magistrates a means whereby the Court may obtain the assistance of skilled medical help where the demcatiour or conduct of the accused suggests mental instability. The Magistrates, whilst fully conscious of their obligation to deal with all persons chargerl strictly within the law, have instituted the procedure owing to the fact that the community has been, and is, going through a period of mental stress which has exhibited itself in many unaccountable ways. Magistrates must be acquainted with the mentality of the person charged, in order that, where possible, remedial measures may be adopted. One cannot say at this stage to what extent the system may be developed; nor the number of offenders who will come within its scope, but there is already cvidence sufficient to justify the step taken. 